\title{
Climatic and Soil Water Balances for the Melon Crop
}

\author{
Jaedson Cláudio Anunciato Mota ${ }^{1}$, Paulo Leonel Libardi ${ }^{2}$, Raimundo Nonato Assis Júnior ${ }^{1}$, \\ Alexsandro Santos Brito ${ }^{3}$, Márcio Godofrêdo Rocha Lobato ${ }^{1}$, Thiago Leite Alencar ${ }^{1}$, \\ Alcione Guimarães Freire ${ }^{1} \&$ Juarez Cassiano Lima Júnior ${ }^{1}$ \\ ${ }^{1}$ Department of Soil Sciences, Federal University of Ceará, Brazil \\ 2 Department of Biosystems Engineering, "Luiz de Queiroz" College of Agriculture, Brazil \\ ${ }^{3}$ Federal Institute Baiano, Guanambi, Brazil \\ Correspondence: Márcio Godofrêdo Rocha Lobato, Department of Soil Sciences, Federal University of Ceará, \\ Brazil. E-mail: marciogrl@hotmail.com
}

Received: October 22, 2017

doi:10.5539/jas.v10n2p116

\author{
Accepted: November 26, 2017 \\ Online Published: January 15, 2018 \\ URL: https://doi.org/10.5539/jas.v10n2p116
}

\begin{abstract}
The correct estimate of the water requirements of a crop, besides favoring its full development, also allows the rational use of water. In this context, this study aimed to evaluate water balance in the soil and estimated through climatic methods for the melon crop. Field water balance was daily determined along a period of 70 days. Climatic water balance was determined based on the reference evapotranspiration estimated by the methods of Penman-Monteith, Thornthwaite and Hargreaves-Samani. It was concluded that climatic methods do not estimate correctly water storage in the soil and, consequently, also the balance. Therefore, they should not substitute the soil water balance method to determine these variables. The water management for the melon crop based on evapotranspiration estimated through climatic methods results in overestimation of the water depth to be applied in the soil, in the initial growth stage, and underestimation in the periods of highest water demand.
\end{abstract}

Keywords: evapotranspiration, irrigation, water storage

\section{Introduction}

Irrigation is essential to meet the water requirements of the plants, especially in regions like Northeast Brazil. This region stands out for the great productive potential, particularly with the melon crop (Cucumis melo L.), responsible for $95 \%$ of the national production (IBGE, 2016). In regions where the scarcity of water resources prevails in most of the time, special care must be taken with respect to water use and management, since it is a limiting factor in the production of agricultural crops (Libardi et al., 2015).

This way, the measurement of the water requirement of a crop should be made, always when possible, based on parameters obtained in situ (Libardi et al., 2015), because they control the availability of water to plants (Hartmann et al., 2012). According to the same authors, changes in the hydraulic soil properties influence the water supply and the consumption by transpiration and, thus, affect the soil water balance. For Timm et al. (2002), water balance performed in the soil is important for rational water management and consequent maximization of yield. However, the soil water balance equation is not always used because of the difficulty of obtaining its components (Ghiberto et al., 2011), since it requires detailed information about the hydraulic soil properties (Ma et al., 2013; Campos et al., 2016). In this context, climatic water balance has been used because its parameters can be easily obtained, since it utilizes data of climatic temporal series.

Nevertheless, since it is a generalized recommendation for completely different situations, the climatic water balance may not represent the actual conditions of water in the soil, and the greatest disadvantage in this type of balance is the high spatial variability of the climatic components (Libardi et al., 2015). The main component for the determination of climatic water balance is the evapotranspiration, which can be estimated through various physical and empirical models, such as Thornthwaite (Th), Penman-Monteith (P-M) (Bruno et al., 2007) and Hargreaves and Samani (H-S) (Arellano \& Irmak, 2016), among others. The difference between these models is in the parameters used to determine the evapotranspiration, because the model of P-M uses data of radiation and wind speed, H-S uses temperature and Th uses temperature and photoperiod (Arellano \& Irmak, 2016). 
It is worth noting that evapotranspiration is influenced by climatic factors (wind speed, radiation, temperature etc.), type of crop, cropping system, environmental conditions and water management (Ma et al., 2017). Therefore, the use of equations based on physical processes should be prioritized rather than empirical equations, which are generally valid only for specific surface and/or climate conditions (Arellano \& Irmak, 2016).

In this perspective, the present study considered the hypothesis that the soil water balance, in situ, for representing the actual conditions of the relationships in the soil-plant-atmosphere system, should not be substituted by the climatic water balance in the estimate of water requirement by the melon crop in the Brazilian semi-arid region. Given the above, this study aimed to evaluate the water balances for the melon crop at field and estimated by the methods of Thornthwaite, Penman-Monteith, Hargreaves-Samani and Hargreaves-Samani with parameters adjusted to the local conditions $\left(\mathrm{H}-\mathrm{S}_{\text {adj }}\right)$.

\section{Material and Methods}

The study was conducted in Baraúna, at the Apodi Plateau, Rio Grande do Norte, Brazil, a municipality with altitude of $16 \mathrm{~m}$, at the geographic coordinates $05^{\circ} 04^{\prime} 48^{\prime \prime} \mathrm{S}$ and $37^{\circ} 37^{\prime} 00^{\prime \prime} \mathrm{W}$. The climate of the region is classified as BSw'h', according to Köppen's classification, with mean annual temperature of $29^{\circ} \mathrm{C}$. The mean rainfall is approximately $750 \mathrm{~mm}_{\text {year }}{ }^{-1}$. The soil of the experimental area is a Haplocambids.

Yellow muskmelon (Cucumis melo L.), variety AF-646, at a spacing of $2.00 \mathrm{~m} \times 0.35 \mathrm{~m}$, was grown in ten 50 -m-long plant rows in a flat area $(20 \mathrm{~m} \times 50 \mathrm{~m})$. At the points corresponding to $1 / 3$ and $2 / 3$ of each plant row, four tensiometers (at a distance of $0.1 \mathrm{~m}$ from each other) were set up at the depths of $0.1,0.2,0.3$ and $0.4 \mathrm{~m}$ (which include most of the effective roots of the muskmelon), adjacent to the irrigation line $(0.1 \mathrm{~m}$ from the plant row) between two selected plants. The tensiometers were read every day between 6 and 7 a.m. Readings were converted to matric potential and then to water content through the fitting equation for soil water retention curves for the corresponding depth.

The field water balance for the melon crop (Cucumis melo L.) was daily determined, along a period of 70 days, between December 29, 2005, and March 2, 2006, considering Equation 1 (Libardi et al. 2015),

$$
\mathrm{P}+\mathrm{I} \pm \mathrm{C}+\mathrm{D}+\mathrm{ET} \pm \mathrm{R}=\Delta \mathrm{WS}
$$

where, P, I, C, D, ET, R and $\Delta$ WS represent, respectively, pluvial precipitation, irrigation depth, capillary rise, internal drainage, crop evapotranspiration, runoff and variation in soil water storage. The values of the processes are in millimeters in all cases. Historic rainfall data and the rainfall observed along the experimental period are presented in Figure 1.

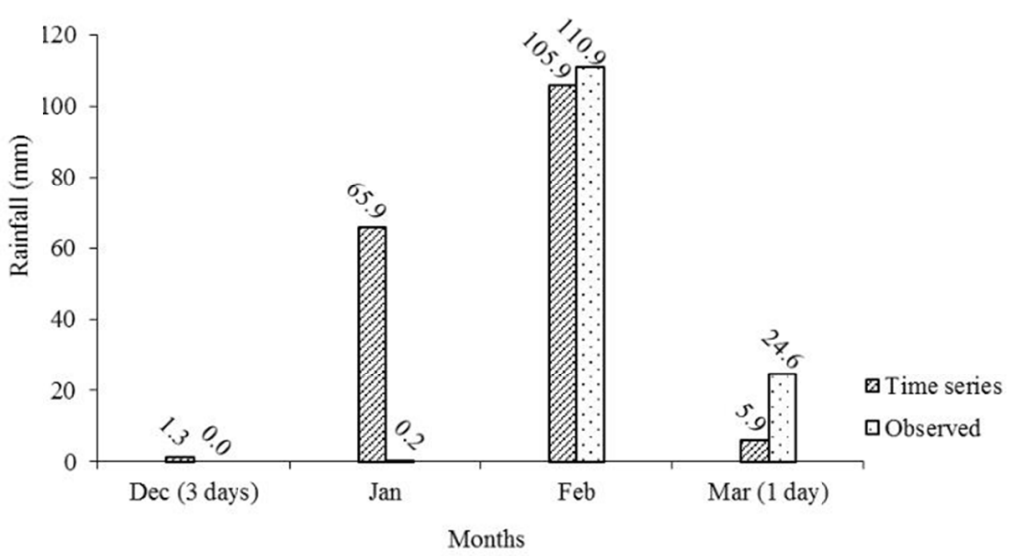

Figure 1. Rainfall from a time series and from the observed data in the period

The control volume of the soil considered for the water balance had soil surface as the upper limit and the effective depth of melon roots, $0.3 \mathrm{~m}$, as the lower limit, thus considering the layer of $0-0.3 \mathrm{~m}$.

Pluvial precipitations were measured using a pluviometer, Ville de Paris model, installed in the experimental area. Drip irrigation was managed to prevent soil water tension from reaching values greater than $40 \mathrm{kPa}$. Internal drainage and capillary rise were estimated by the Darcy-Buckingham equation, 


$$
\mathrm{q}_{\mathrm{z}}=-\mathrm{K}(\theta) \cdot\left[\frac{\varphi_{\mathrm{t}}(0.2 \mathrm{~m})-\varphi_{\mathrm{t}}(0.4 \mathrm{~m})}{0.2}\right]
$$

where, $\mathrm{K}(\theta)$ is the hydraulic conductivity as a function of soil water content for the depth of $0.3 \mathrm{~m} ; \phi_{\mathrm{t}}(0.2 \mathrm{~m})$ and $\phi_{\mathrm{t}}(0.4 \mathrm{~m})$ are the total potentials at the depths of 0.2 and $0.4 \mathrm{~m}$, respectively. Runoff (R) was disregarded, because the area is considered as flat. Volumetric water content $(\theta)$ was obtained through readings of tensiometers at the depths of $0.1,0.2$ and $0.3 \mathrm{~m}$. Water storage and storage variation were daily calculated through the trapezoid rule. Crop evapotranspiration (ET) was obtained through direct measurement of all components of the field balance, thus leaving it as unknown.

The climatic water balance for the melon crop was determined based on the methods of Penman-Monteith (P-M), Thornthwaite (T), Hargreaves-Samani (H-S) and Hargreaves-Samani with data adjusted to the local conditions $\left(\mathrm{H}-\mathrm{S}_{\mathrm{adj}}\right)$. The daily means of ETo were calculated through the previously cited methods using data from the conventional weather station of the Federal University of the Semi-Arid Region.

ETc (maximum or potential crop evapotranspiration) was determined through the multiplication of the reference evapotranspiration by the crop coefficient $(\mathrm{Kc})$. The $\mathrm{Kc}$ was considered according to the development stage of the melon crop, as $0.5,0.8,1.05$ and 0.75 for the initial, vegetative, fruiting and maturation stages, respectively. Potential reference evapotranspiration was daily measured through the Class A Pan method. The variation of soil water storage was estimated using data of water conditions in the soil and the climate of the region, according to Equation 3,

$$
\pm \Delta \mathrm{WS}=\mathrm{P}+\mathrm{I}-\mathrm{ET}-\mathrm{D}
$$

where, $\pm \Delta$ WS represents the variation of water storage in the soil $(\mathrm{mm})$ relative to the layer of $0-0.30 \mathrm{~m}$; the negative sign indicates water deficit while the positive sign indicates water excess. When $\Delta \mathrm{WS}$ is negative, drainage is null $(\mathrm{D}=0)$; when it is positive, the excess includes runoff and drainage.

The Penman-Monteith model is classified by the Food and Agriculture Organization (FAO) as a standard equation to estimate ETo (potential evapotranspiration). Therefore, it is advisable to adjust empirical models of evapotranspiration through this standard (Allen et al., 1998). The model is represented by Equation 4,

$$
E T_{0}=\frac{0.408 \times \Delta \times(R n-G)+\gamma \times \frac{900}{T m+273} \times V_{2}\left(e_{s}-e_{a}\right)}{\Delta+\gamma\left(1+0.34 V_{2}\right)}
$$

where, ETo is the reference evapotranspiration $\left(\mathrm{mm} \mathrm{day}^{-1}\right), \mathrm{Rn}$ is the total net radiation of the grass $\left(\mathrm{MJ} \mathrm{m}^{-2} \mathrm{~d}^{-1}\right)$, $\mathrm{G}$ is the heat flow density in the soil $\left(\mathrm{MJ} \mathrm{m}^{-2} \mathrm{~d}^{-1}\right), T \mathrm{~m}$ is the mean daily air temperature $\left({ }^{\circ} \mathrm{C}\right), \mathrm{U}_{2}$ is mean daily

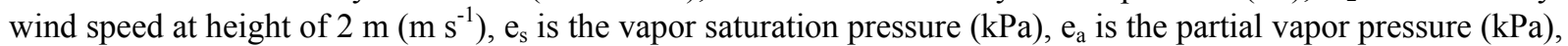
$\mathrm{e}_{\mathrm{s}}-\mathrm{e}_{\mathrm{a}}$ is the vapor saturation deficit $(\mathrm{kPa}), \Delta$ is the slope of the vapor pressure curve at the point $\mathrm{Tm}\left(\mathrm{kPa}^{\circ} \mathrm{C}^{-1}\right)$ and $\gamma$ is the psychrometric coefficient $\left(\mathrm{kPa}^{\circ} \mathrm{C}^{-1}\right)$.

The partial vapor pressure $\left(\mathrm{e}_{\mathrm{a}}\right)$ was estimated by substituting the dew point temperature by the minimum daily air temperature minus $2{ }^{\circ} \mathrm{C}\left(\mathrm{Td}=\mathrm{Tn}-2{ }^{\circ} \mathrm{C}\right)$, as suggested by Allen et al. (1998) for semi-arid climates, Equation 5,

$$
e^{0}\left(T_{m}\right)=0.6108 \exp \left(\frac{17.27 \times T_{d}}{t_{d}+237.3}\right)
$$

Global solar radiation $\left(R_{\mathrm{s}}\right)$ was estimated through the method of Hargreaves and Samani (1982), Equation 6,

$$
R s=K_{r s} \times(T x-T n)^{0.5} \times R_{a}
$$

where, $K_{\mathrm{rs}}$ is the empirical adjustment coefficient - the value depends on the distance from the coast, equal to 0.19 for coastal region and 0.16 for continental region, Tx and Tn are maximum and minimum air temperatures $\left({ }^{\circ} \mathrm{C}\right)$ and $\mathrm{Ra}$ is the radiation on top of the atmosphere $\left(\mathrm{MJ} \mathrm{m}^{-2} \mathrm{~d}^{-1}\right)$.

The model of Thornthwaite (1948) estimates $\mathrm{ET}_{0}$ using data of mean daily temperature or of a certain period (T) and photoperiod $(\mathrm{N})$ as entry parameters. In the present study, since the mean annual temperature is higher than $26.5^{\circ} \mathrm{C}, \mathrm{ET}_{\mathrm{p}}$ was calculated by Equation 7 ,

$$
E T p=-415.85+32.24 T-0.43 T^{2}
$$

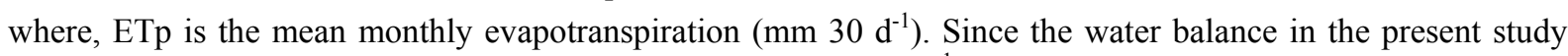
was performed daily, $\mathrm{ET}_{0}$ was estimated using Equation $8\left(\mathrm{~mm} \mathrm{day}^{-1}\right)$, described in Sentelhas et al. (2010),

$$
E T_{0}=\left(\frac{E T p}{30}\right) \cdot\left(\frac{N}{12}\right)
$$


The time of maximum insolation $(\mathrm{N})$ was determined by Equation 9 , in which $\omega_{\mathrm{s}}$ is the angle of solar radiation at sunset,

$$
N=\frac{24}{\pi} \omega_{s}
$$

The model of Hargreaves and Samani (1985) estimates ETo using only the values of maximum, minimum and mean air temperatures and radiation on top of the atmosphere, Equation 10,

$$
E T_{0}=\alpha(T x-T n)^{\beta} \times(T m+17.8) \times R_{a} \times 0.408
$$

where, $\alpha$ is an empirical parameter, whose original value was 0.0023 , and $\beta$ is an exponential empirical parameter, whose original value was 0.5 .

Prior to comparison and calculation of water balance in the soil using field data, the parameters of the H-S equation were calibrated, thus adjusting the empirical model for ETo estimation to the studied site. The parameters of the Hargreaves and Samani (1985) equation were adjusted using Microsoft Excel ${ }^{\circledR}$, through the Solver application, following the methodology described and used by Wraith and Or (1998). This technique allows to minimize the sum of square deviation, so that the closer to zero the difference between the values obtained through P-M and H-S, the better the calibration, Equation 11,

where, $\mathrm{n}$ is the number of observations.

$$
\sum_{\mathrm{i}=1}^{\mathrm{n}}\left(\mathrm{PM}_{\mathrm{i}}-\mathrm{HS}_{\mathrm{i}}\right)^{2}=0
$$

The statistical indices suggested by Legates and McCabe Jr (1999): Willmott's index of agreement (d), Nash-Sutcliffe coefficient (E) and root mean squared error (RMSE), were used to evaluate the models, $\mathrm{X}$

$$
\begin{gathered}
\mathrm{d}=1-\left[\frac{\sum_{\mathrm{i}=1}^{\mathrm{n}}\left(\mathrm{Y}_{\mathrm{i}}-\mathrm{X}_{\mathrm{i}}\right)^{2}}{\sum_{\mathrm{i}=1}^{\mathrm{n}}\left(\left|\mathrm{Y}_{\mathrm{i}}-\mathrm{X}\right|+\left|\mathrm{X}_{\mathrm{i}}-\mathrm{X}\right|\right)^{2}}\right] \\
E=1-\frac{\sum_{i=1}^{n}\left(Y_{i}-X_{i}\right)^{2}}{\sum_{i=1}^{n}\left(X_{i}-X\right)^{2}} \\
R M S E=\sqrt{\frac{\sum_{i=1}^{n}\left(Y_{i}-X_{i}\right)^{2}}{n}}
\end{gathered}
$$

where, $\mathrm{X}_{\mathrm{i}}$ is the value obtained at field (independent variable), $\mathrm{Y}_{\mathrm{i}}$ is the value estimated by the equation based on climatic data, $\mathrm{X}$ is the mean value obtained at field and $\mathrm{Y}$ is the mean value estimated based on climatic data.

The components were compared by linear regression, analysis of the coefficients applying the Student's t-test at 0.10 probability level, correlation and/or comparisons between sequenced values. Climatic balances used the following data: available water capacity $=26 \mathrm{~mm}$, field capacity $=79 \mathrm{~mm}$, permanent wilting point $=53 \mathrm{~mm}$, latitude $\phi=-05^{\circ} 08^{\prime}$, year 2006, initial NDA (number of days in the Julian calendar) $=3$, corresponding to January 03 , and $\Delta \mathrm{t}=1$ day.

\section{Results and Discussion}

Based on field measurements, the evaluated soil volume maintained, in terms of water depth, approximately 15 $\mathrm{mm}$ during all the studied period. When the estimate was made using climatic water balances, this condition was not observed, regardless of the method used, with underestimation until the 50 days after planting and overestimation in the remaining period (Figure 2). 


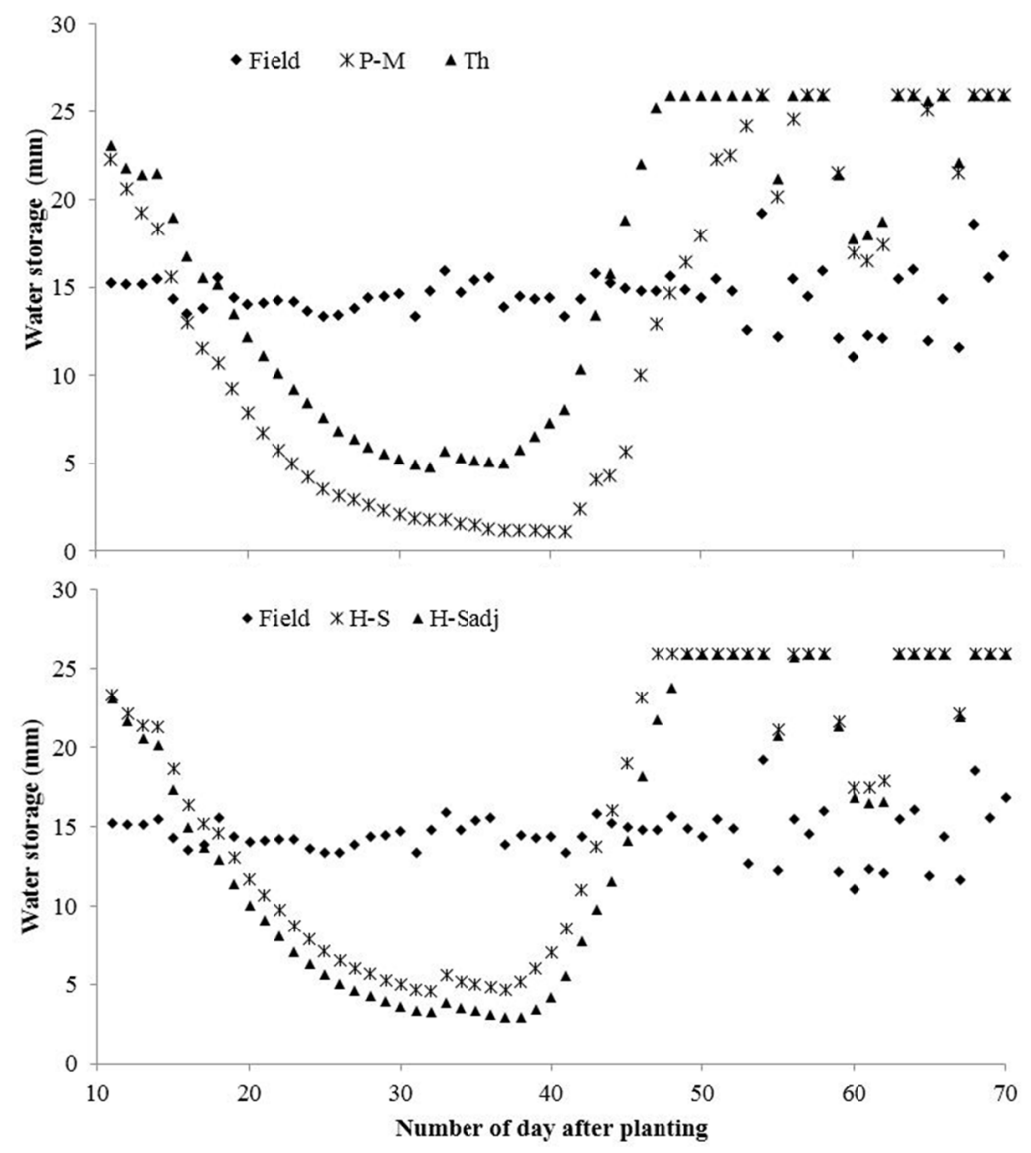

Figure 2. Soil water storage by field and climatic methods. Penman-Monteith (P-M), Thornthwaite (Th), Hargreaves-Samani (H-S) e Hargreaves-Samani adjusted ( $\left.\mathrm{H}-\mathrm{S}_{\text {adj }}\right)$

The significant differences between field and climatic methods occur because climatic methods do not consider soil properties in water retention and storage. For example, according to Libardi et al. (2015), when soil surface is drying, the water flow through capillarity ceases and it compromises water evaporation, which favors the maintenance of soil moisture. Climatic models, for not considering soil attributes (P-M is a combined physical model that uses air temperature and humidity, solar radiation and wind speed; Th uses solar radiation and temperature; H-S uses only air temperature), have limitations to predict the actual behavior of the water in the soil.

The regression analysis between water storage determined through field and climatic methods (Figure 3) reinforces what was previously stated. The low correlation $(0.15,0.20,0.20$ and 0.19 for P-M, Th, H-S and $\mathrm{H}-\mathrm{S}_{\text {adj }}$, respectively) evidences the low relationship between water storage measured at field and that estimated through climatic methods. It should be highlighted that the correlation found for all methods was not significant and, therefore, it was not necessary to analyze the coefficients of intercept and slope. Thus, it can be claimed that water storage in the soil should not be estimated through climatic methods, since this process is highly complex and depends on soil physical attributes, such as texture, structure and organic matter content. 

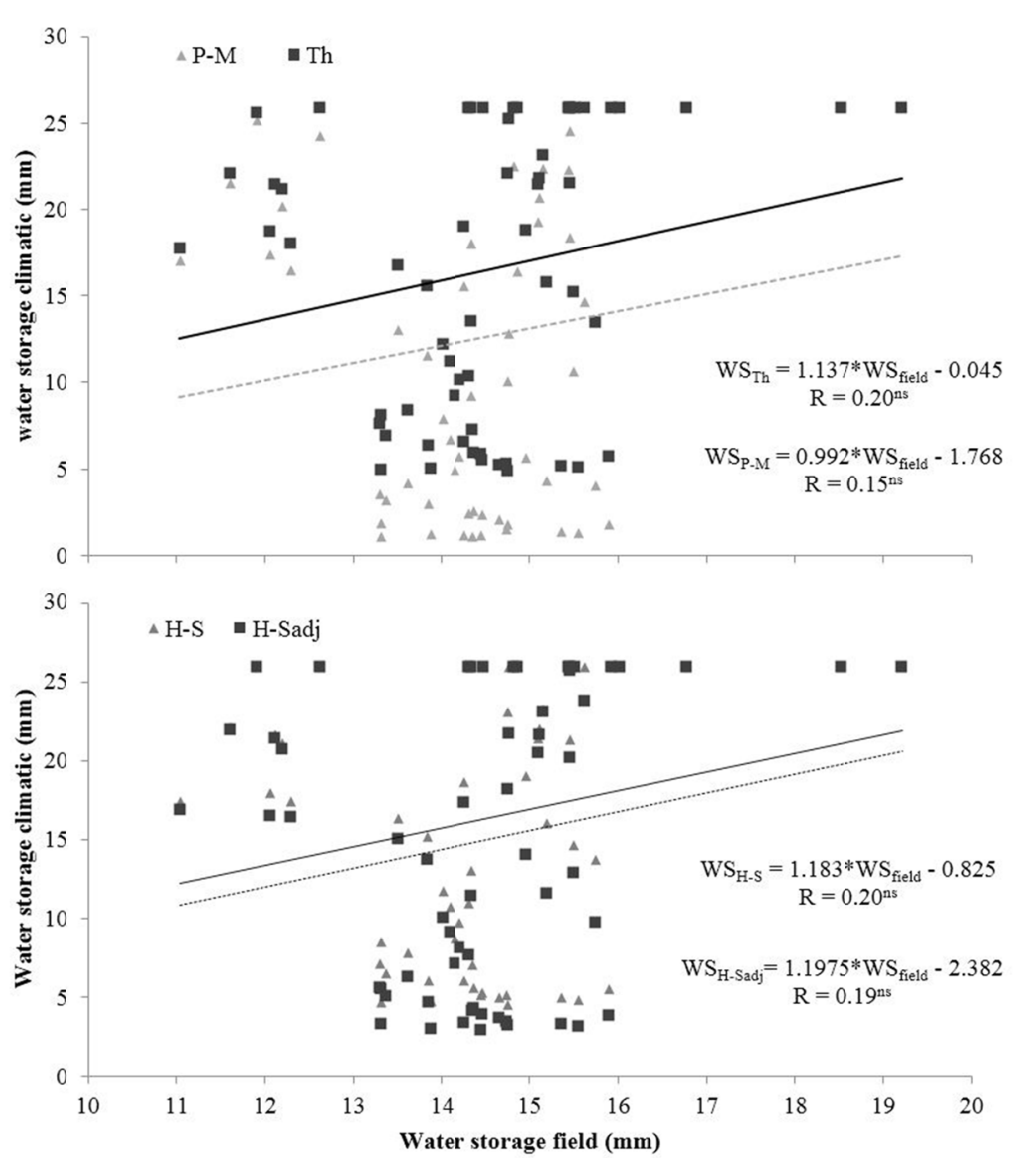

Figure 3. Regression analysis between soil water storage determined through field and climatic methods. Penman-Monteith (P-M), Thornthwaite (Th), Hargreaves-Samani (H-S) and Hargreaves-Samani adjusted $\left(\mathrm{H}-\mathrm{S}_{\mathrm{adj}}\right) .{ }^{\mathrm{ns}}$ not significant at $1 \%$ probability

The water balance in the soil, represented by the variation in water storage ( $\triangle \mathrm{WS}$ ) is presented in Figure 4 . Since moisture was maintained always close to field capacity - more details in Libardi et al. (2015), there was almost no variation of water storage at field, remaining always close to zero. The climatic methods showed similar behavior for $\Delta \mathrm{WS}$ in the first 50 days after planting. However, in the remaining period, when there was greater oscillation of $\Delta \mathrm{WS}$ at field, especially due to the pluvial precipitations presented in Figure 1, the climatic methods did not estimate it correctly. Such oscillation reflects the balance of available energy of the soil surface. According to Pereira et al. (2009), on the surface of a humid soil, most energy is converted to latent heat of vaporization, a condition not observed in a soil with water restriction, in which energy is used to heat the air. 


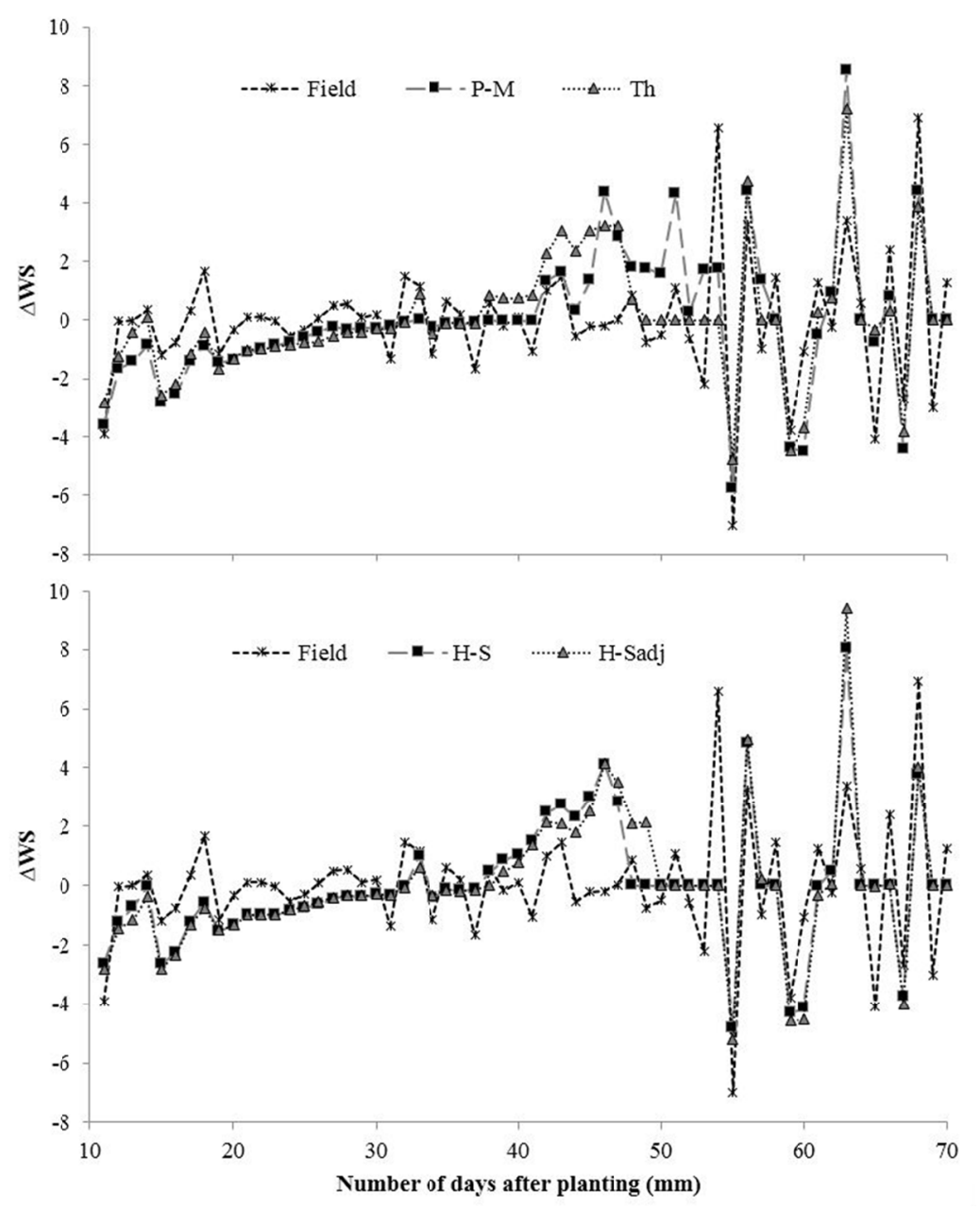

Figure 4. Soil water storage variation ( $\Delta \mathrm{WS}$ ) by field and climatic methods. Penman-Monteith (P-M), Thornthwaite (Th), Hargreaves-Samani (H-S) and Hargreaves-Samani adjusted (H-S $\left.\mathrm{adj}_{\mathrm{aj}}\right)$

A reflex of this oscillation can be observed in Figure 5, which shows the data of linear regression analysis between $\triangle \mathrm{WS}$ estimated at field and through climatic methods. There was low correlation when these methods were compared with the $\Delta \mathrm{WS}$ estimated at field $\left(0.63,0.61,0.57\right.$ and 0.57 , for P-M, Th, H-S and H-S $\mathrm{S}_{\text {adj, }}$, respectively). Regarding the analysis of the intercept and slope, Table 1, the methods $\mathrm{H}-\mathrm{S}_{\text {adj }} \times \mathrm{H}-\mathrm{S}, \mathrm{H}-\mathrm{S}_{\text {adj }} \times \mathrm{Th}$ and $\mathrm{H}-\mathrm{S}_{\mathrm{adj}} \times \mathrm{P}-\mathrm{M}$ did not differ for intercept and slope, thus allowing the utilization of a single regression equation to represent the relationship between climatic methods and the field method. 

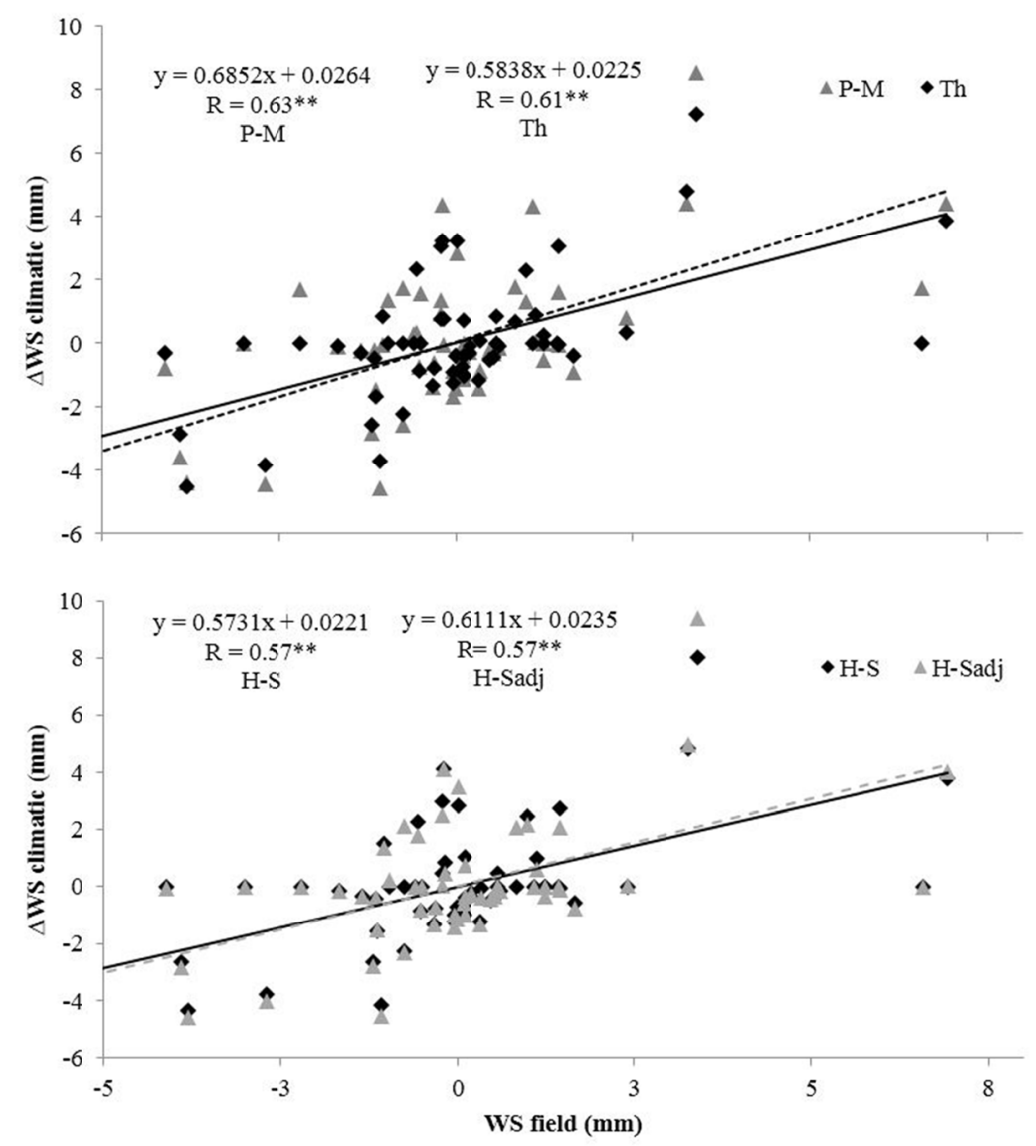

Figure 5. Regression analysis between variation in water storage ( $\Delta \mathrm{WS})$ by field and climatic methods. Penman-Monteith (P-M), Thornthwaite (Th), Hargreaves-Samani (H-S) and Hargreaves-Samani adjusted $\left(\mathrm{H}-\mathrm{S}_{\mathrm{adj}}\right) . * *$ significant at $1 \%$ probability

It is important to point out that some components of the water balance, particularly drainage, provide information on the possibility of leaching of nutrients and consequent contamination of the water table. Figure 6 shows the linear regression of the internal drainage measured at field compared with those estimated through climatic methods, since in the present study the runoff was disregarded because the area had a flat relief. Unlike the results found by Bruno et al. (2007), there were high correlations between climatic methods and the field method ( $0.97,0.95,0.95$ and 0.94 for P-M, Th, H-S and $\mathrm{H}-\mathrm{S}_{\text {adj }}$, respectively), all significant at 0.01 probability level. 

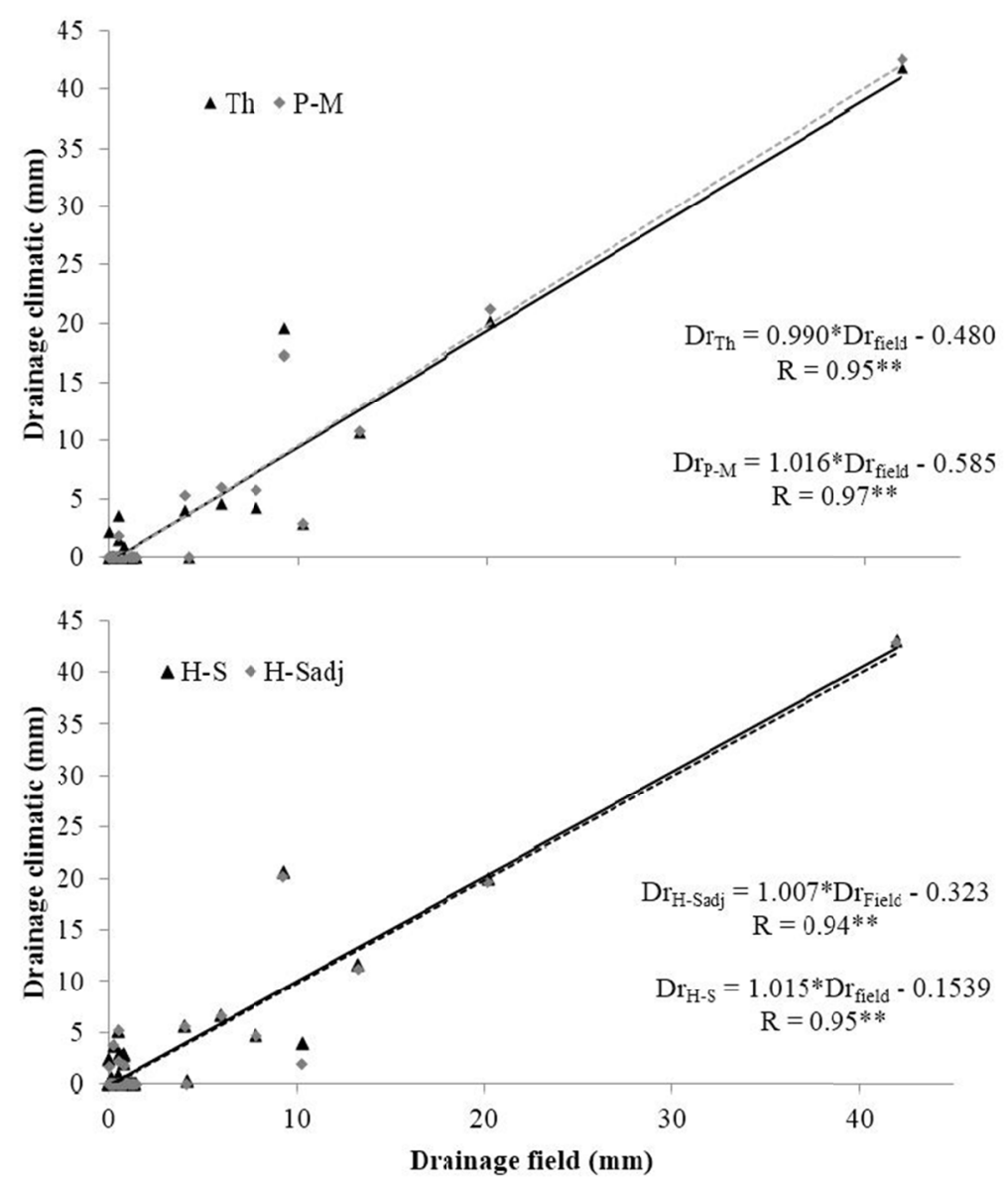

Figure 6. Linear regression between the internal drainage measured at field and estimated through climatic methods. Penman-Monteith (P-M), Thornthwaite (Th), Hargreaves-Samani (H-S) e Hargreaves-Samani adjusted $\left(\mathrm{H}-\mathrm{S}_{\mathrm{adj}}\right) .{ }^{* *}$ significant at $1 \%$ probability

Regarding the analysis of the coefficients (Table 1), the methods $\mathrm{H}-\mathrm{S}_{\mathrm{adj}} \times \mathrm{H}-\mathrm{S}, \mathrm{H}-\mathrm{S}_{\mathrm{adj}} \times \mathrm{Th}$ and $\mathrm{H}-\mathrm{S}_{\mathrm{adj}} \times \mathrm{P}-\mathrm{M}$ did not differ in relation to the intercept and slope, allowing the utilization of a single regression equation to represent the relationship between these methods and the field method. On the other hand, the methods $\mathrm{H}-\mathrm{S} \times \mathrm{Th}$, $\mathrm{H}-\mathrm{S} \times \mathrm{P}-\mathrm{M}$ and $\mathrm{Th} \times \mathrm{P}-\mathrm{M}$ exhibit significant differences with respect to the intercept. 
Table 1. Significance test for the difference between the coefficients of the regression equations by the estimation methods of the water balance components

\begin{tabular}{|c|c|c|c|c|c|}
\hline \multirow{2}{*}{ Water balance components (mm) } & \multirow{2}{*}{ Method } & \multicolumn{2}{|c|}{ Slope } & \multicolumn{2}{|c|}{ Intercept } \\
\hline & & t observed & $\mathrm{t}$ tabulated & t observed & $\mathrm{t}$ tabulated \\
\hline \multirow[t]{6}{*}{ Variation in water storage } & $\mathrm{H}-\mathrm{Sadj} \times \mathrm{H}-\mathrm{S}$ & 0.242 & 1.567 & 0.008 & 1.567 \\
\hline & H-Sadj $\times$ Th & 0.178 & 1.567 & 0.005 & 1.567 \\
\hline & H-Sadj $\times$ P-M & 0.462 & 1.567 & 0.016 & 1.567 \\
\hline & $\mathrm{H}-\mathrm{S} \times \mathrm{Th}$ & 0.073 & 1.567 & 0.002 & 1.567 \\
\hline & $\mathrm{H}-\mathrm{S} \times \mathrm{P}-\mathrm{M}$ & 0.729 & 1.567 & 0.024 & 1.567 \\
\hline & $\mathrm{Th} \times \mathrm{P}-\mathrm{M}$ & 0.678 & 1.567 & 0.024 & 1.567 \\
\hline \multirow[t]{6}{*}{ Drainage } & $\mathrm{H}-\mathrm{Sadj} \times \mathrm{H}-\mathrm{S}$ & 0.133 & 1.567 & 0.864 & 1.567 \\
\hline & H-Sadj $\times$ Th & 0.268 & 1.567 & 0.802 & 1.567 \\
\hline & H-Sadj $\times$ P-M & 0.165 & 1.567 & 1.336 & 1.567 \\
\hline & $\mathrm{H}-\mathrm{S} \times \mathrm{Th}$ & 0.410 & 1.567 & 1.666 & 1.567 \\
\hline & $\mathrm{H}-\mathrm{S} \times \mathrm{P}-\mathrm{M}$ & 0.014 & 1.567 & 2.201 & 1.567 \\
\hline & $\mathrm{Th} \times \mathrm{P}-\mathrm{M}$ & 0.488 & 1.567 & 2.201 & 1.567 \\
\hline \multirow[t]{6}{*}{ Evapotranspiration } & H-Sadj $\times$ H-S & 0.777 & 1.567 & 0.143 & 1.567 \\
\hline & $\mathrm{H}-\mathrm{Sadj} \times \mathrm{Th}$ & 0.165 & 1.567 & 0.256 & 1.567 \\
\hline & H-Sadj $\times$ P-M & 1.710 & 1.567 & 0.449 & 1.567 \\
\hline & $\mathrm{H}-\mathrm{S} \times \mathrm{Th}$ & 0.716 & 1.567 & 0.114 & 1.567 \\
\hline & $\mathrm{H}-\mathrm{S} \times \mathrm{P}-\mathrm{M}$ & 2.554 & 1.567 & 0.306 & 1.567 \\
\hline & $\mathrm{Th} \times \mathrm{P}-\mathrm{M}$ & 2.046 & 1.567 & 0.306 & 1.567 \\
\hline
\end{tabular}

The evapotranspiration obtained through field method and climatic methods ( $\mathrm{P}-\mathrm{M}, \mathrm{Th}, \mathrm{H}-\mathrm{S}$ and $\left.\mathrm{H}-\mathrm{S}_{\mathrm{adj}}\right)$ is presented in Figure 7. Since these methods are based on different principles to estimate the removal of water from the soil, the first one with measurements directly in the soil and the second one with climatic data, it became evident the difference for the variable in all stages of the melon phenological cycle, differing from the result found by Bruno et al. (2007). These authors compared water balances at field and through climatic methods, and observed similarities in evapotranspiration, water storage variation in the soil and drainage. These differences may result from the number of days of the balance, because, unlike Bruno et al. (2007), the balance was daily calculated in this study, and/or from the different edaphoclimatic conditions. 


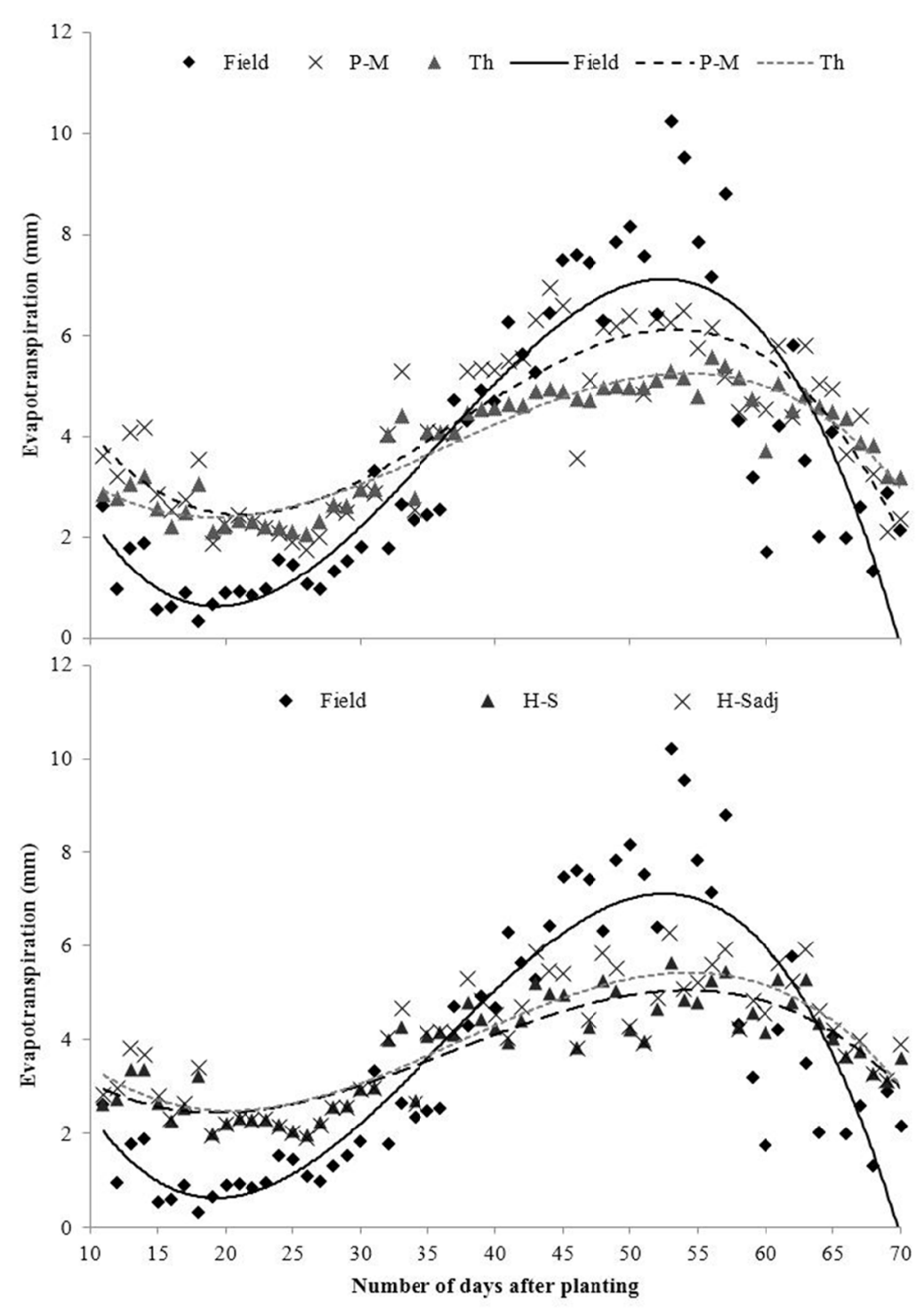

Figure 7. Evapotranspiration obtained through field and climatic methods. Penman-Monteith (P-M),

Thornthwaite (Th), Hargreaves-Samani (H-S) and Hargreaves-Samani adjusted (H-S $\left.{ }_{\text {adj }}\right)$

The climatic balances showed similar behaviors, both overestimating crop evapotranspiration in the first 35 days after planting and underestimating it between 35 and 60 days after planting. Although it has some advantages, the estimate of evapotranspiration through climatic methods should not substitute the determination performed at field, because it does not represent the actual water requirement of the plants.

Figure 8 shows the linear regressions between the evapotranspiration through the soil water balance method and climatic methods. It was observed that the correlation coefficients are high, from 0.76 to 0.83 , and significant at 0.01 probability level, which indicates good correlation between the evapotranspiration measured at field and that estimated through any of the evaluated climatic methods. 


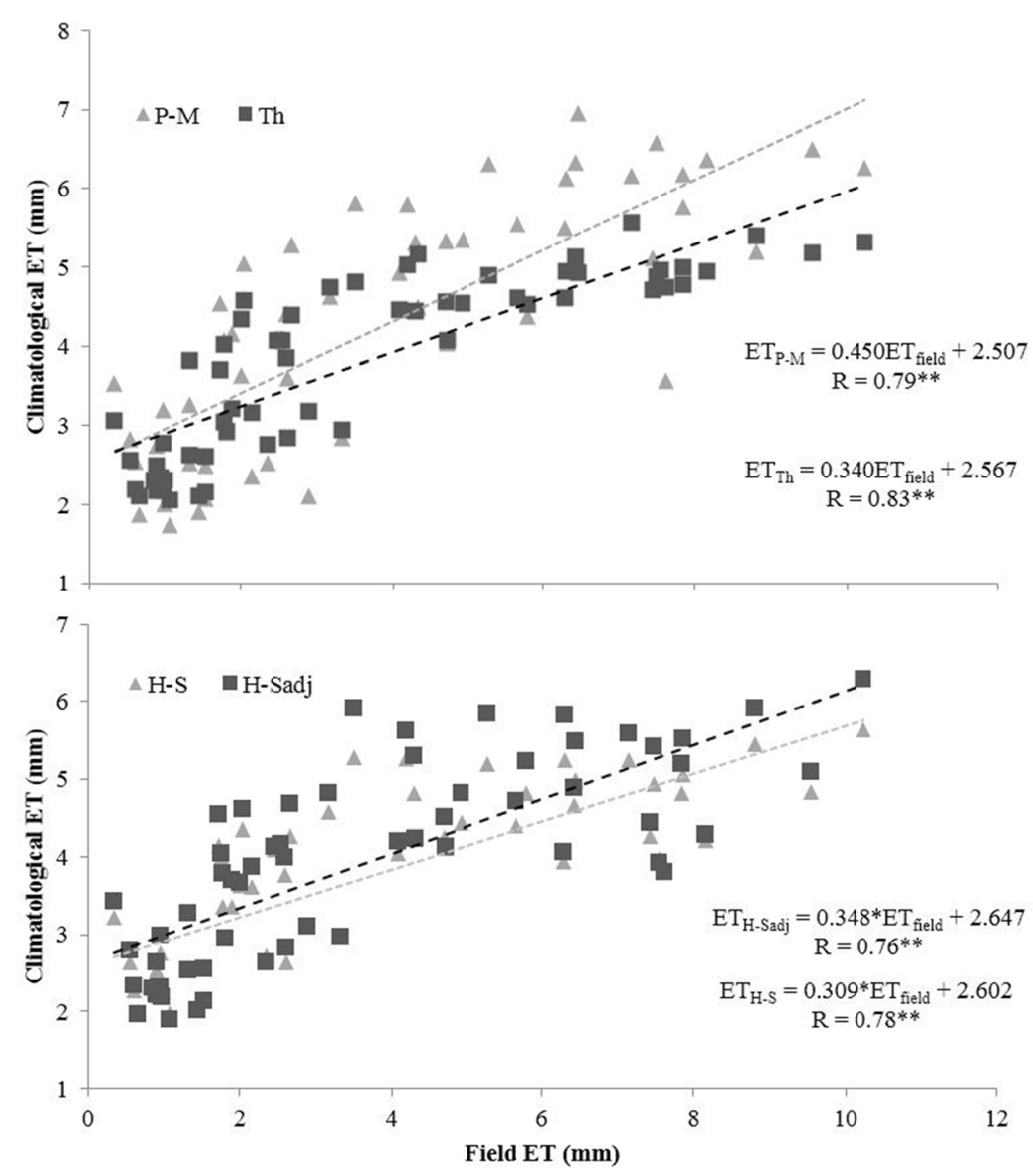

Figure 8. Linear regressions between the evapotranspiration through the soil water balance and climatic methods. Penman-Monteith (P-M), Thornthwaite (Th), Hargreaves-Samani (H-S) e Hargreaves-Samani adjusted (H-S $\mathrm{S}_{\mathrm{aj}}$ ). ** significant at $1 \%$ probability

According to the intercepts, it became evident the overestimation of evapotranspiration through climatic methods in the initial stage of the melon crop. For example, in a situation in which the evapotranspiration measured at field is equal to zero, the estimated values are 2.51 to $2.65 \mathrm{~mm}$ per day. Indeed, it is confirmed that the water management for the melon crop based on evapotranspiration estimated through climatic methods results sometimes in overestimation of the water depth to be applied in the soil, especially in the initial growth stage, and sometimes in underestimation, notably in the periods of highest water demand.

According to the coefficients of slope and intercept of the linear regression equations of evapotranspiration, for the methods H-S $\mathrm{S}_{\mathrm{adj}} \times \mathrm{H}-\mathrm{S}, \mathrm{H}-\mathrm{S}_{\mathrm{adj}} \times \mathrm{Th}$ and $\mathrm{H}-\mathrm{S} \times \mathrm{Th}$, the observed values of the Student's t-test were lower than those of the calculated $t$; thus, the null hypothesis was accepted, i.e., there is no significant difference between the intercept and slope of the lines (Table 1). This result indicates that, for evapotranspiration, there is no difference between the methods $\mathrm{H}-\mathrm{S}_{\mathrm{adj}} \times \mathrm{Th}$; thus, a single regression equation can be used to represent both methods. The same interpretation can be made for the methods $\mathrm{H}-\mathrm{S}_{\text {adj }} \times \mathrm{Th}$ and $\mathrm{H}-\mathrm{S} \times \mathrm{Th}$.

Regarding the indices applied to evaluate the field and climatic methods, Willmott's index of agreement (d) evaluates the agreement between independent and dependent variables, ranging from 0 to 1 ; the closer to 1 , the better the uniformity between measured and estimated values. The statistical evaluation of the ET-estimation models compared with the field data (Table 2) demonstrated that the P-M model showed the best results for all analyzed variables. 
Table 2. Statistical indexes of Willmott (d), Nash-Sutcliffe (E) and root mean squared error (RMSE), for the comparison of soil water balance by Penman-Monteith (P-M), Thornthwaite (Th), Hargreaves-Samani (H-S) and Hargreaves-Samani adjusted (H-Sadj) climatic methods

\begin{tabular}{lllll}
\hline & P-M & Th & H-S & H-S adj \\
\hline $\mathrm{d}$ & 0.809 & 0.744 & 0.704 & 0.738 \\
$\mathrm{E}$ & 0.551 & 0.513 & 0.462 & 0.480 \\
RMSE $\left(\mathrm{mm} \mathrm{day}^{-1}\right)$ & 1.801 & 1.877 & 1.972 & 1.939 \\
\hline
\end{tabular}

The Nash-Sutcliffe coefficient (E) was also the highest one for the P-M model, indicating that it is the most efficient to estimate melon ET under the semi-arid conditions. For the estimation model to be classified as satisfactory, its value must be at least 0.50 (Moriasi et al., 2007) and, therefore, the results indicate the viability of using the models P-M and Th to estimate ET.

In turn, the errors, represented by the root mean squared error, were all above $1.8 \mathrm{~mm}^{-1}$ day $^{-1}$, although they were lower than those calculated by Jacovides and Kontoyiannis (1995) with the Penman-Monteith equation in a study on statistical models utilized in the analyses of equations that estimate ETo.

\section{Conclusions}

The climatic methods do not estimate correctly water storage in the soil and, consequently, also the balance; hence, they should not substitute the soil water balance method to determine these variables.

The water management for the melon crop based on evapotranspiration estimated through climatic methods results in overestimation of the water depth to be applied in the soil in the initial growth stage and in underestimation in the periods of highest water demand.

\section{References}

Allen, R. G., Pereira, L. S., Raes, D., \& Smith, M. (1998). Crop evapotranspiration guidelines for computing crop water requirements (p. 300, Irrigation and Drainage Paper, 56). Rome: FAO.

Arellano, M. G., \& Irmak, S. (2016). Reference (potential) evapotranspiration. I: comparison of temperature, radiation, and combination-based energy balance equations in humid, sub humid, arid, semiarid, and Mediterranean-type climates. Journal of Irrigation and Drainage Engineering, 142, 1-21. https://doi.org/ 10.1061/(ASCE)IR.1943-4774.0000978

Bruno, I. P., Silva, A. L., Reichardt, K., Dourado Neto, D., Bacchi, O. O. S., \& Volpe, C. A. (2007). Comparison between climatological and field water balances for a coffee crop. Scientia Agrícola, 64, 215-220. https://doi.org/10.1590/S0103-90162007000300001

Campos, I., González-Piqueras, J., Carrara, A., Villodre, J., \& Calera, A. (2016). Estimation of total available water in the soil layer by integrating actual evapotranspiration data in a remote sensing-driven soil water balance. Journal of Hydrology, 534, 427-439. https://doi.org/10.1016/j.jhydrol.2016.01.023

Ghiberto, P. J., Libardi, P. L., Brito, A. S., \& Trivelin, P. C.O. (2011). Components of the water balance in soil with sugarcane crops. Agricultural Water Management, 102, 1-7. https://doi.org/10.1016/j.agwat.2011. 09.010

Hargreaves, G. H., \& Samani, Z. A. (1982). Estimating potential evapotranspiration. Journal of Irrigation and Drainage Engineering, 108, 225-230.

Hargreaves, G. H., \& Samani, Z. A. (1985). Reference crop evapotranspiration from temperature. Applied Engineering in Agriculture, 1, 96-99. https://doi.org/10.13031/2013.26773

Hartmann, P., Zink, A., Fleige, H., \& Horn, R. (2012). Effect of compaction, tillage and climate change on soil water balance of Arable Luvisols in Northwest Germany. Soil \& Tillage Research, 124, 211-218. https://doi.org/10.1016/j.still.2012.06.004

IBGE. (2016). Instituto Brasileiro de Geografia e Estatística (IBGE) Municipal Crop Production. Retrieved March 21, 2016, from http://biblioteca.ibge.gov.br/visualizacao/periodicos/66/pam_2014_v41_br.pdf

Jacovides, C. P., \& Kontoyiannis, H. (1995). Statistical procedures for the evaluation of evapotranspiration computing models. Agricultural Water Management, 27, 365-371. https://doi.org/10.1016/0378-3774 (95)01152-9 
Legates, D. R., \& McCabe, G. J. (1999). Evaluating the use of "goodness-of-fit" measures in hydrologic and hydro climatic model validation. Water Resources Research, 35, 233-241. https://doi.org/10.1029/1998WR 900018

Libardi, P. L., Mota, J. C. A., Assis Júnior, R. N., Brito, A. S., \& Amaro Filho, J. (2015). Water balance components in covered and uncovered soil growing irrigated muskmelon. Revista Brasileira de Ciência do Solo, 39, 1322-1334. https://doi.org/10.1590/01000683rbcs20140713

Ma, Q., Zhang, J., Sun, C., Guo, E., Zhang, F., \& Wang, M. (2017). Changes of reference evapotranspiration and its relationship to dry/wet conditions based on the aridity index in the songnen grassland, northeast china. Water, 9(5), 316. https://doi.org/10.3390/w9050316

Ma, Y., Feng, S., \& Song, X. (2013). A root zone model for estimating soil water balance and crop yield responses to deficit irrigation in the North China Plain. Agricultural Water Management, 127, 13-24. https://doi.org/10.1016/j.agwat.2013.05.011

Moriasi, D. N., Arnold, J. G., Van Liew, M. W., Bingner, R. L., Harmel, R. D., \& Veith, T. L. (2007). Model evaluation guidelines for systematic quantification of accuracy in watershed simulations. American Society of Agricultural and Biological Engineers, 50, 885-900. https://doi.org/10.13031/2013.23153

Pereira, D. R., Yanagi, S. N. M., Mello, C. R., Silva, A. M., \& Silva, L. A. (2009). Performance of the reference evapotranspiration estimating methods for the Mantiqueira range region, MG, Brazil. Ciência Rural, 39, 2488-2493. https://doi.org/10.1590/S0103-84782009000900016

Sentelhas, P. C., Gillespie, T. J., \& Santos, E. A. (2010). Evaluation FAO Penmam-Montheith and alternative methods for estimating reference evapotranspiration with missing data in Southern Ontario, Canada. Agricultural Water Management, 97, 635-644. https://doi.org/10.1016/j.agwat.2009.12.001

Thornthwaite, C. W. (1948). An approach toward a rational classification of climate. Geographical Review, 38, 55-94. https://doi.org/10.2307/210739

Timm, L. C., Oliveira, J. C. M., Tominaga, T. T., Cássaro, F. A. M., Reichardt, K., \& Bacchi, O. O. S. (2002). Water balance of a sugarcane: Quantitative and qualitative aspects of its measurement. Revista Brasileira de Engenharia Agricola e Ambiental, 6, 57-62. https://doi.org/10.1590/S1415-443662002000100011

Willmott, C. J. (1981). On the validation of models. Physical Geography, 2, 184-194. Retrieved from http://www.tandfonline.com/doi/abs/10.1080/02723646.1981.10642213

Wraith, J. M., \& Or, D. (1998). Nonlinear parameter estimation using spreadsheet software. Journal Natural Resources and Life Science Education, 27, 13-19.

\section{Copyrights}

Copyright for this article is retained by the author(s), with first publication rights granted to the journal.

This is an open-access article distributed under the terms and conditions of the Creative Commons Attribution license (http://creativecommons.org/licenses/by/4.0/). 